\title{
A COMPARATIVE STUDY OF THE BLOOD CONCENTRATIONS AND URINARY EXCRETION OF SULFAPYRIDINE AND SULFANILAMIDE AFTER SINGLE DOSES OF SULFAPYRIDINE AND RELATED COMPOUNDS ADMINISTERED BY VARIOUS ROUTES
}

\author{
BY F. H. LASKEY TAYLOR, FRANCIS C. LOWELL, MARGARET A. ADAMS, \\ WILLIAM C. SPRING, JR., AND MAXWELL FINLAND \\ WITH THE TECHNICAL ASSISTANCE OF NANCY E. MAREAN \\ (From the Thorndike Memorial Laboratory, Second and Fourth Medical Services (Harvard), \\ Boston City Hospital and the Department of Medicine, Harvard Medical School, Boston)
}

(Received for publication September 18, 1939)

We have recently had available a solution containing a high concentration of sulfapyridine in 50 per cent glucose which can be conveniently administered orally, subcutaneously and intravenously (1). This offered an opportunity to study the effect of the route of administration of a drug containing sulfapyridine on the blood level and urinary excretion and to compare it with other derivatives of sulfanilamide. The results of the biochemical studies are presented in this paper. The bacteriological and clinical results are presented elsewhere $(1,2)$.

\section{METHODS AND MATERIALS}

Four subjects were studied. They were maintained on a house diet and their average fluid intake was about 3 liters daily. There was no demonstrable kidney damage present in any of these patients. In the case of Subject $B$, who is reported in detail, the phenolsulfonphthalein excretion was normal and showed no change after the investigation was completed. In no instance did vomiting occur following the administration of any of the drugs investigated, nor was there any diarrhoea during the period of observation. Subject A was a 26-year-old white man weighing 127 pounds (58 $\mathrm{kgm}$.), suffering from gonococcal arthritis. Subject B was a 43-year-old white male, weighing 152 pounds $(69 \mathrm{kgm}$.), who had arthritis thought to be of gonococcal origin. Subject C was a 62-year-old white male, weighing 150 pounds (68 $\mathrm{kgm}$.), who was under treatment for a parotid abscess which followed facial erysipelas. Subject D was a 39year-old white male weighing 156 pounds $(70 \mathrm{kgm}$.), who had active gonococcal arthritis.

The glucose-sulfapyridine solution used in this study was prepared for us by the Research Division of the Lederle Laboratories. It contained ${ }^{1} 9.5$ per cent total

${ }^{1}$ We are indebted to the Research Division of the Lederle Laboratories for assays on the drug. They report the glucose-sulfapyridine compound to be a glucose anil of the general formula:

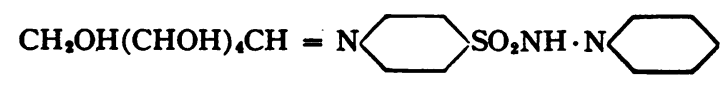

sulfapyridine in 50 per cent glucose solution. Approximately 97 per cent of the sulfapyridine was reported to be in the form of a glucose-sulfapyridine compound, as determined by a direct nitrous acid method. Hydrolysis of the compound takes place rapidly in the presence of cold dilute acids. For this reason the colorimetric method of Marshall and Litchfield (3) cannot be used to determine the amount of sulfapyridine in combination with glucose either in the original solution or in the blood.

During this investigation the glucose-sulfapyridine solution and sulfanilamide were administered intravenously, subcutaneously and orally; sodium sulfapyridine was given intravenously, and sulfapyridine was given orally. Each drug was given in 4.75 gram amounts in $500 \mathrm{ml}$. of fluid. Physiological saline was used for the parenteral injections and tap water for the oral doses. The intravenous injections were given over a period of an hour, the subcutaneous ones in about $11 / 2$ hours, and the oral doses were divided into 6 parts and given over a period of an hour. Some of the studies were repeated in individual subjects.

All urine samples were saved. Specimens were obtained simultaneously with the blood samples as far as possible. Determination of sulfapyridine or sulfanilamide was made on all samples. Collection of urine was 'continued until it showed no appreciable amounts of the drug. Before commencing a study of a second drug or changing the route of administration, a further period of 24 hours was usually allowed to elapse.

In vitro studies were conducted by adding sufficient amounts of the compound under investigation to oxalated whole blood to give concentrations of the substance between 8 and $10 \mathrm{mgm}$. per $100 \mathrm{ml}$. The hematocrit was determined in each instance and corrected for the oxalate effect. Samples were removed at various times and the concentration of the drug in the whole blood and plasma was determined.

Determinations of sulfapyridine or sulfanilamide were made by Marshall and Litchfield's method (3), and glucose determinations by the method of Folin and Wu (4).

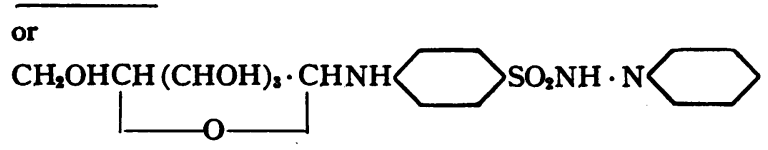




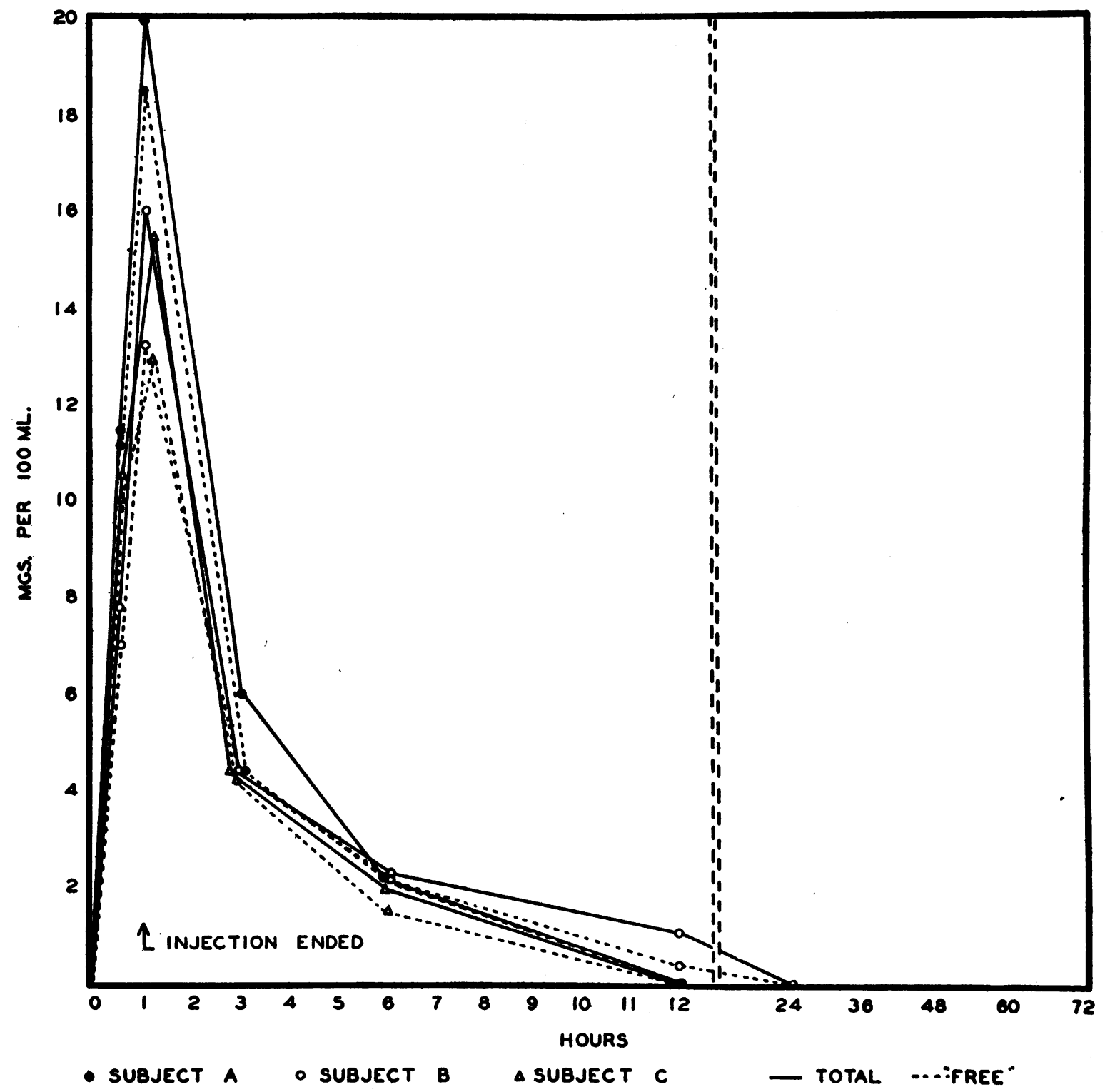

Fig. 1. Effect of Intravenous Injection of Glucose Sulfapyridine on the Blood Levez

EXPERIMENTAL

The effect of the intravenous administration of glucose sulfapyridine, sodium sulfapyridine and sulfanilamide on the blood level and urinary excretion of sulfapyridine and sulfanilamide, respectively

The sulfapyridine concentrations of the blood in three subjects injected with glucose sulfapyridine intravenously are shown in Figure 1 . The data for subject $B$, who was given all the drugs by all the routes used in this study, are shown in
Table I. (This subject's excretion differed in some respects from the other subjects studied in spite of good phenolsulphonphthalein excretion.) During the period of administration the blood level of sulfapyridine rose rapidly, reaching levels between 15 and $20 \mathrm{mgm}$. per $100 \mathrm{ml}$. of blood at the end of the injection. The fall in concentration of the drug was equally rapid, only traces being present in the circulating blood 11 hours after the injection ended.

There was a rise in blood glucose comparable to that found after the intravenous injection of an 
equivalent amount of glucose over a period of 1 hour (Table II). However, this temporary hyperglycemia was not accompanied by a glycosuria. The sulfapyridine was rapidly excreted into the urine and was recovered completely in 24 hours. Between 11 and 27 per cent was recovered while the injection was still in progress.

About 70 per cent of the drug was present in the urine in the conjugated form as determined by Marshall's method (3). Whether this conjugated compound is the acetyl-derivative was not determined. Even in the samples containing large amounts of conjugated sulfapyridine, there was no detectable glycosuria (Table II). Presumably the glucose compound was not being excreted as such.

The urinary excretion of the drug was some- what dependent on diuresis. There was, however, a direct relationship between the blood level of sulfapyridine and the amount of the drug excreted in the urine.

Following the injection of sodium sulfapyridine the maximum blood levels were not as high as those obtained for the glucose compound, but significant amounts of both free and total sulfapyridine were present 12 hours after the injection. The blood contained traces of free sulfapyridine and determinable amounts of total sulfapyridine 36 hours after injection (Table I and Figure 2). Between 88 and 100 per cent of the circulating sulfapyridine at the end of the injection period was in the free form. In two patients this partition was rapidly reduced so that in 12 hours be-

TABLE I

Effect of administration of certain derivatives of sulfanilamide on the blood level and urinary excretion of these substances in Subject $B$

\begin{tabular}{|c|c|c|c|c|c|c|c|c|c|c|c|c|c|c|}
\hline \multirow{3}{*}{ Compound } & \multirow{3}{*}{ Route } & \multirow{3}{*}{ Time* } & \multicolumn{3}{|c|}{ Blood } & \multicolumn{8}{|c|}{ Urine } & \multirow{3}{*}{ Remarks } \\
\hline & & & \multicolumn{3}{|c|}{$\begin{array}{l}\text { Concentration } \\
\text { of drug }\end{array}$} & \multirow{2}{*}{$\begin{array}{l}\text { Vol- } \\
\text { ume }\end{array}$} & \multirow{2}{*}{$\begin{array}{l}\text { Water } \\
\text { excre- } \\
\text { tion }\end{array}$} & \multicolumn{2}{|c|}{$\begin{array}{l}\text { Concentra- } \\
\text { tion of drug }\end{array}$} & \multicolumn{2}{|c|}{$\begin{array}{l}\text { Excretion } \\
\text { of drug }\end{array}$} & \multicolumn{2}{|c|}{$\begin{array}{l}\text { Per cent of } \\
\text { administered } \\
\text { dose excreted } \\
\text { (cumulative) }\end{array}$} & \\
\hline & & & Freet & Total & \multirow{3}{*}{$\frac{\begin{array}{c}\text { Con- } \\
\text { ju- } \\
\text { gated }\end{array}}{}$} & & & Free & Total & Free & Total & Free & Total & \\
\hline \multirow[b]{2}{*}{$\begin{array}{l}\text { Glucose } \\
\text { Sulfapyridine }\end{array}$} & \multirow[b]{2}{*}{ Intravenous } & \multirow[b]{2}{*}{$\begin{array}{c}\text { hours } \\
\\
1 \\
3 \\
6 \\
121 \\
241 \\
46\end{array}$} & \multicolumn{2}{|c|}{$\begin{array}{l}\text { mgm. per } \\
100 \mathrm{ml} .\end{array}$} & & \multirow[b]{2}{*}{\begin{tabular}{|c|}
$m l$. \\
\\
120 \\
300 \\
800 \\
1400 \\
1350 \\
2600
\end{tabular}} & \multirow{2}{*}{$\begin{array}{c}\begin{array}{c}\text { ml. } \\
\text { per } \\
\text { minute }\end{array} \\
2.0 \\
2.5 \\
4.3 \\
3.7 \\
1.9 \\
2.0\end{array}$} & \multicolumn{2}{|c|}{$\begin{array}{l}\text { mgm. per } \\
100 \mathrm{ml} .\end{array}$} & \multicolumn{2}{|c|}{$\underset{\text { period }}{\operatorname{mgm}}$ for } & \multicolumn{2}{|c|}{ per cent } & \multirow[b]{2}{*}{$\begin{array}{l}\text { Injection ended at } 1 \text { hour } \\
\text { All values as sulfapyridine }\end{array}$} \\
\hline & & & $\begin{array}{r}10.6 \\
18.4 \\
4.5 \\
2.2 \\
\mathrm{~T} \\
\mathrm{~T} \\
0\end{array}$ & $\begin{array}{r}11.0 \\
20.0 \\
5.8 \\
2.3 \\
\mathbf{T} \\
\mathbf{T} \\
0\end{array}$ & & & & $\mid \begin{array}{r}107.5 \\
174.7 \\
49.5 \\
12.4 \\
4.5 \\
T\end{array}$ & \begin{tabular}{|r}
468 \\
775 \\
180 \\
44 \\
17 \\
3
\end{tabular} & $\begin{array}{r}129 \\
524 \\
396 \\
174 \\
61\end{array}$ & $\begin{array}{r}562 \\
2325 \\
1440 \\
615 \\
230 \\
78\end{array}$ & $\begin{array}{r}2.7 \\
13.7 \\
22.0 \\
25.7 \\
27.0\end{array}$ & $\begin{array}{r}11.8 \\
60.7 \\
91.2 \\
104.1 \\
109.0 \\
110.6\end{array}$ & \\
\hline $\begin{array}{l}\text { Sodium } \\
\text { Sulfapyridine }\end{array}$ & Intravenous & $\begin{array}{c}1 \\
1 \\
3 \\
6 \\
12 \\
24 \\
36 \\
48 \\
72 \\
94 \\
119\end{array}$ & $\begin{array}{l}4.4 \\
9.5 \\
6.9 \\
5.0 \\
2.9 \\
T \\
T \\
T \\
T\end{array}$ & $\begin{array}{r}5.3 \\
10.3 \\
8.5 \\
7.4 \\
5.4 \\
3.2 \\
1.8 \\
T \\
T\end{array}$ & $\begin{array}{r}17 \\
8 \\
19 \\
32 \\
46 \\
100 \\
100\end{array}$ & $\begin{array}{r}620 \\
30 \\
300 \\
600 \\
980 \\
780 \\
1640 \\
1000 \\
2900 \\
2800 \\
240\end{array}$ & $\begin{array}{l}1.0 \\
2.5 \\
3.3 \\
2.7 \\
1.1 \\
2.3 \\
1.4 \\
2.0 \\
2.1\end{array}$ & $\begin{array}{r}4.7 \\
47.1 \\
40.8 \\
26.8 \\
22.6 \\
23.6 \\
4.7 \\
3.4 \\
0.8 \\
T \\
T\end{array}$ & $\begin{array}{r}6.3 \\
65.6 \\
64.1 \\
74.3 \\
84.0 \\
179.1 \\
45.2 \\
40.7 \\
6.9 \\
1.3 \\
1.5\end{array}$ & $\begin{array}{r}29 \\
14 \\
122 \\
161 \\
222 \\
184 \\
77 \\
34 \\
23\end{array}$ & $\begin{array}{r}39 \\
20 \\
192 \\
446 \\
823 \\
1397 \\
741 \\
407 \\
200 \\
36 \\
4\end{array}$ & $\begin{array}{r}0.6 \\
0.9 \\
3.5 \\
6.9 \\
11.5 \\
15.4 \\
17.0 \\
17.7 \\
18.2\end{array}$ & \begin{tabular}{r|}
0.8 \\
1.2 \\
5.3 \\
14.7 \\
32.0 \\
61.4 \\
77.4 \\
85.5 \\
89.7 \\
90.5 \\
90.6
\end{tabular} & $\begin{array}{l}\text { Injection ended at } 1 \text { hour } \\
\text { All values as sulfapyridine }\end{array}$ \\
\hline Sulfanilamide & Intravenous & $\begin{array}{l}\quad \\
2 \frac{1}{3} \\
5 \\
12 \\
24 \\
36 \\
48 \\
68 \\
71 \frac{1}{2}\end{array}$ & $\begin{array}{c}8.1 \\
11.7 \\
8.3 \\
7.1 \\
4.3 \\
2.7 \\
1.6 \\
T \\
T\end{array}$ & \begin{tabular}{r|}
8.1 \\
13.4 \\
9.5 \\
8.6 \\
7.2 \\
4.9 \\
3.6 \\
2.8 \\
$T$
\end{tabular} & $\begin{array}{r}0 \\
13 \\
13 \\
17 \\
40 \\
45 \\
56 \\
100\end{array}$ & $\begin{array}{r}75 \\
215 \\
430 \\
1150 \\
740 \\
1400 \\
1850 \\
680 \\
1300 \\
610\end{array}$ & $\begin{array}{l}5.0 \\
7.2 \\
3.6 \\
6.4 \\
1.8 \\
1.9 \\
2.6 \\
0.9 \\
1.9 \\
3.1\end{array}$ & $\begin{array}{r}24.8 \\
54.0 \\
55.8 \\
24.8 \\
42.5 \\
29.1 \\
13.1 \\
12.2 \\
6.2 \\
3.8\end{array}$ & $\begin{array}{l}24.8 \\
58.7 \\
70.0 \\
30.6 \\
70.2 \\
65.7 \\
43.7 \\
60.1 \\
30.9 \\
24.8\end{array}$ & $\begin{array}{r}19 \\
116 \\
240 \\
285 \\
314 \\
407 \\
242 \\
83 \\
81 \\
23\end{array}$ & $\begin{array}{r}19 \\
126 \\
301 \\
352 \\
519 \\
920 \\
808 \\
408 \\
402 \\
151\end{array}$ & \begin{tabular}{|r|}
0.4 \\
2.8 \\
7.9 \\
13.9 \\
20.5 \\
29.1 \\
34.1 \\
35.8 \\
37.5 \\
38.0
\end{tabular} & $\begin{array}{r}0.4 \\
3.0 \\
9.3 \\
16.7 \\
27.6 \\
47.0 \\
64.0 \\
72.6 \\
81.1 \\
84.3\end{array}$ & $\begin{array}{l}\text { Injection ended hour } \\
\text { All values as sulfanilamide }\end{array}$ \\
\hline $\begin{array}{l}\text { Glucose } \\
\text { Sulfapyridine }\end{array}$ & Subcutaneous & $\begin{array}{r}1 \\
3 \\
6 \\
12 \\
24 \\
36 \\
48 \\
69 \\
72\end{array}$ & $\begin{array}{c}1.8 \\
4.6 \\
4.0 \\
2.0 \\
\text { T } \\
\text { Sl.T. } \\
\text { Si.T. } \\
0\end{array}$ & $\begin{array}{c}2.5 \\
6.6 \\
5.2 \\
3.3 \\
\text { T } \\
\text { Si.T. } \\
\text { Si.T. } \\
0\end{array}$ & . & $\begin{array}{r}650 \\
380 \\
1000 \\
1100 \\
2000 \\
900 \\
2900 \\
250\end{array}$ & $\begin{array}{l}3.6 \\
2.1 \\
2.8 \\
1.5 \\
2.8 \\
1.2 \\
2.3 \\
1.4\end{array}$ & $\begin{array}{r}18.2 \\
62.5 \\
32.2 \\
27.3 \\
1.3 \\
1.2 \\
T \\
T\end{array}$ & \begin{tabular}{|r|}
117.0 \\
290.1 \\
165.5 \\
86.2 \\
8.1 \\
5.9 \\
1.3 \\
1.7
\end{tabular} & \begin{tabular}{|c|}
118 \\
237 \\
322 \\
306 \\
26 \\
10.8
\end{tabular} & \begin{tabular}{|r}
761 \\
1102 \\
1655 \\
948 \\
162 \\
53 \\
37 \\
4
\end{tabular} & $\begin{array}{r}2.5 \\
7.0 \\
13.8 \\
20.1 \\
20.6 \\
20.8\end{array}$ & $\begin{array}{l}16.0 \\
39.2 \\
73.9 \\
93.9 \\
97.3 \\
98.4 \\
99.2 \\
99.3\end{array}$ & $\begin{array}{l}\text { Injection ended } 1 \frac{1}{1} \text { hours } \\
\text { All values as sulfapyridine }\end{array}$ \\
\hline
\end{tabular}


TABLE I-Continued

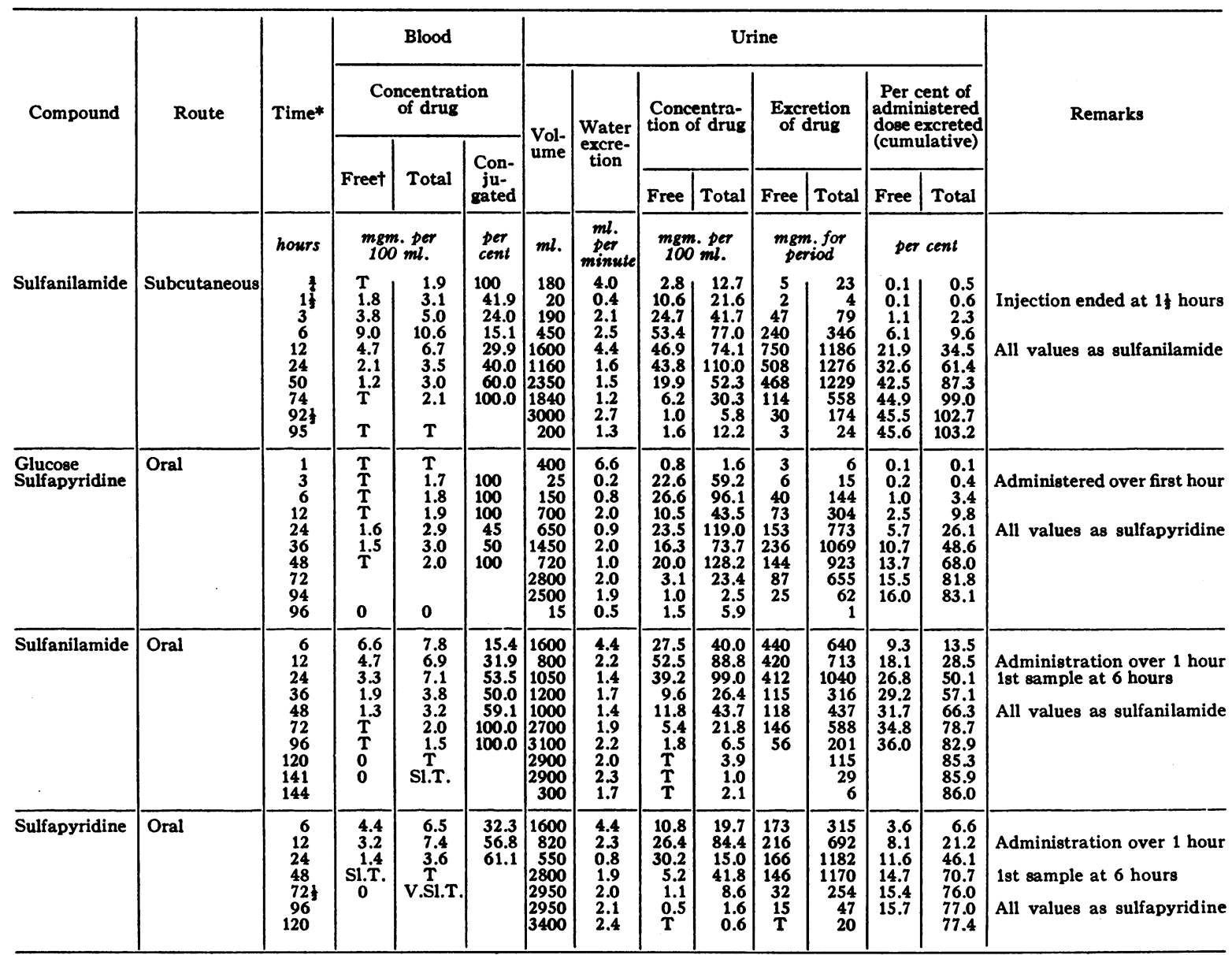

* All times recorded from commencement of administration of drug.

†The values given for "free " sulfapyridine following the administration of glucose sulfapyridine refer only to the values given by the Marshall method without hydrolysis (3) and do not imply that the sulfapyridine was present in the free form. T = Trace. Sl.T. = Slight trace. V.SI.T. = Very slight trace.

TABLE II

The effect of the intravenous administration of glucose and of glucose sulfapyridine on the concentration of glucose in the blood and urine of Subject B

\begin{tabular}{|c|c|c|c|c|}
\hline \multirow{2}{*}{ Time } & \multicolumn{2}{|c|}{ Glucose } & \multicolumn{2}{|c|}{ Glucose sulfapyridine } \\
\hline & $\begin{array}{c}\text { Blood } \\
\text { glucose }\end{array}$ & $\begin{array}{c}\text { Urine } \\
\text { glucose }\end{array}$ & $\begin{array}{c}\text { Blood } \\
\text { glucose }\end{array}$ & $\underset{\text { Ulucose }}{\text { Urine }}$ \\
\hline $\begin{array}{c}\text { hours } \\
\text { Fasting .......... } \\
1 \text { hour after injec.. } \\
1 \text { hour after injec.. } \\
2 \text { hours after injec. } \\
3 \text { hours after injec. } \\
4 \text { hours after injec. } \\
6 \text { hours after injec. } \\
12 \text { hours after } \\
\text { injec................ }\end{array}$ & $\begin{array}{c}\text { mgm. per } \\
100 \text { ml. } \\
90.9 \\
144.5 \\
171.8 \\
115.6 \\
96.6 \\
84.4\end{array}$ & $\begin{array}{l}\text { grams per } \\
100 \text { ml. } \\
\text { Less than } 0.10 \\
\text { Less than } 0.10 \\
\text { Less than } 0.10 \\
\text { Less than } 0.10 \\
\text { Less than } 0.10 \\
\text { Less than } 0.10\end{array}$ & $\begin{array}{c}\text { mgm. per } \\
100 \text { ml. } \\
115.0 \\
181.1 \\
227.5 \\
95.8\end{array}$ & $\begin{array}{c}\text { grams per } \\
100 \mathrm{ml} . \\
0.25 \\
0.20 \\
0.20 \\
\text { Less than } 0.10 \\
\text { Less than } 0.10\end{array}$ \\
\hline
\end{tabular}

tween 40 and 46 per cent was circulating as the conjugated drug.
The excretion of sulfapyridine into the urine after the injection of sodium sulfapyridine was much slower than in the case of the glucose compound (Table I). In 96 hours, however, 90 per cent of the administered sulfapyridine had been excreted. About 75 per cent of the total sulfapyridine excreted was in the form of the conjugated drug and this percentage was approximately the same whether the sodium salt or the glucose compound was injected.

The effect of diuresis on the urinary excretion of sulfapyridine was not marked in Subject B, but in the other two individuals the maximum excretion of the drug into the urine corresponded to a period of maximum diuresis. There was no parallelism between the blood level and the ex- 


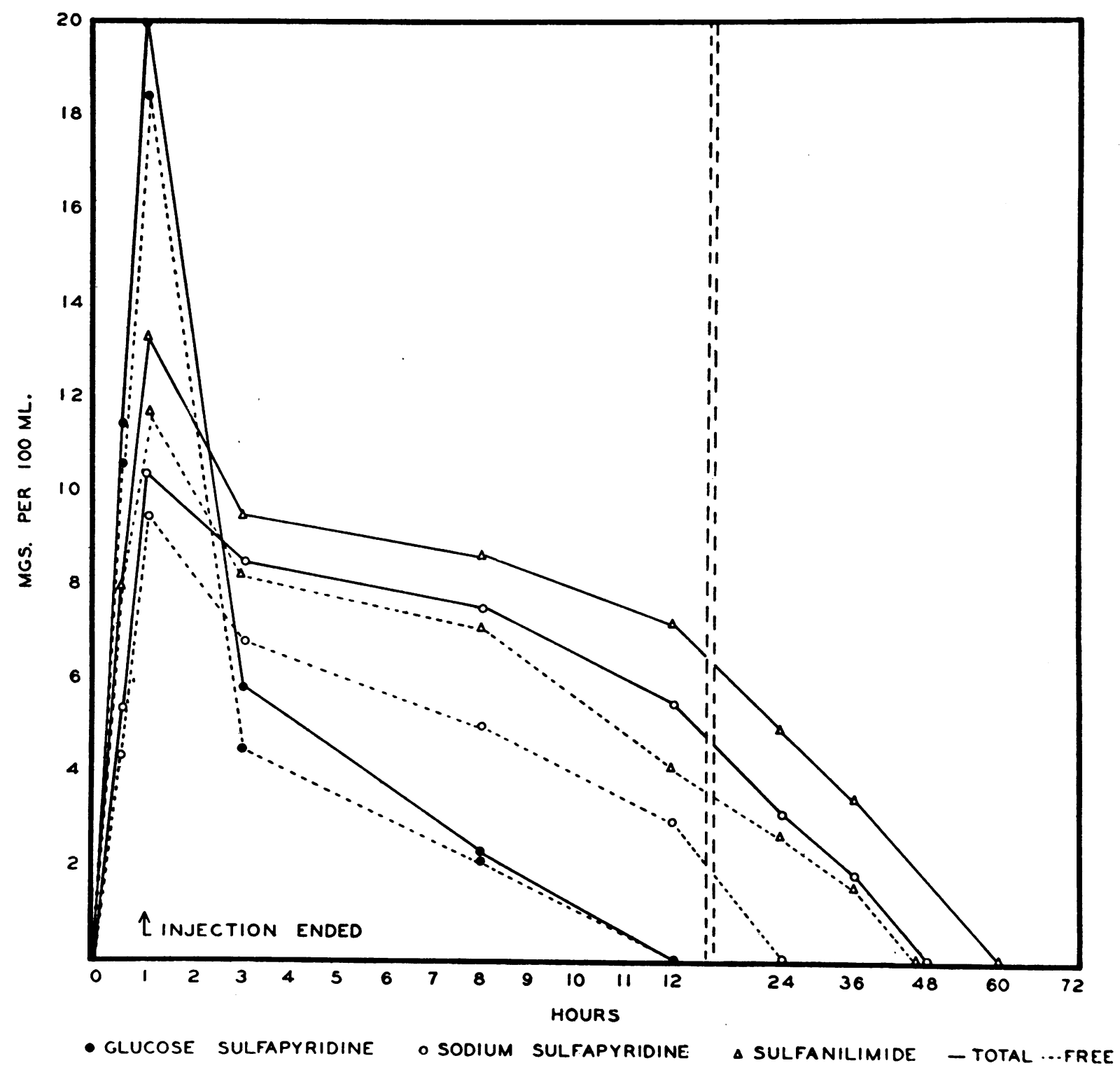

Fig. 2. (Subject B.) Blood Levels after Intravenous Administration of Thre Sulfanilamide Derivatives

cretion rate of sulfapyridine such as obtained for the glucose compound.

The injection of sulfanilamide gave similar results except that there was a somewhat lower concentration of conjugated sulfanilamide present in the urine than that found after the injection of a corresponding amount of sodium sulfapyridine.
The effect of the subcutaneous administration of glucose sulfapyridine and sulfanilamide on the blood level and urinary excretion of sulfapyridine and sulfanilamide respectively

The blood concentrations of sulfapyridine following the subcutaneous injection of glucose sul- 


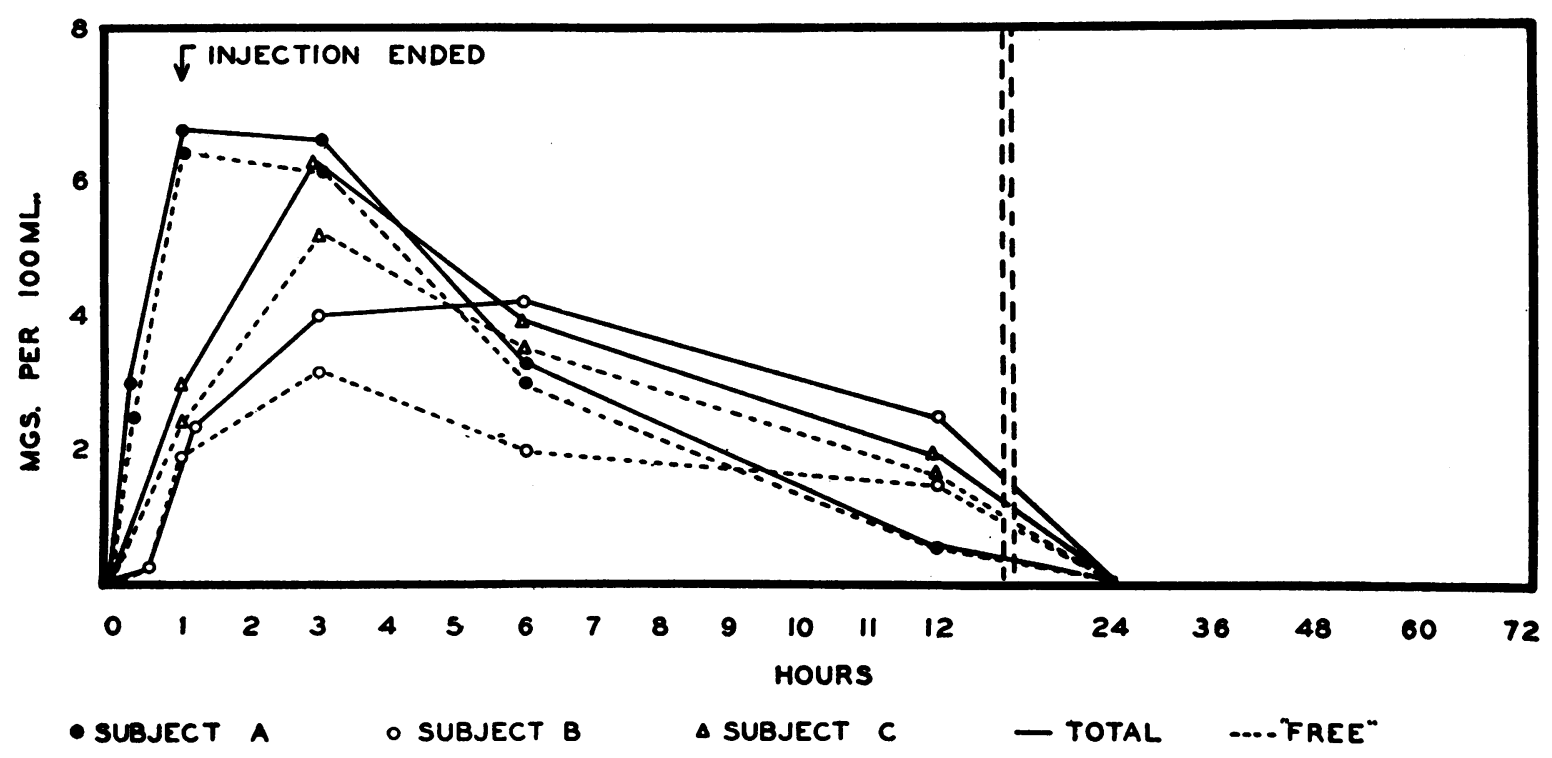

Fig. 3. Effect of Subcutaneous Injection of Glucose Sulfapyridine on the Blood Level

fapyridine are shown for the three subjects in Figure 3, and the data obtained on a second occasion in Subject B are shown in Table I. The concentration of sulfapyridine in the blood rose more slowly and to a lower maximum than when glucose sulfapyridine was given intravenously. Determinable amounts were present in the circulating blood for at least 12 hours. There was no marked increase in the conjugated form as was the case when the sodium salt or sulfanilamide was given intravenously.

The subcutaneous injection of glucose sulfapyridine was followed by a hyperglycemia comparable to that produced by a similar amount of glucose. There was, however, no corresponding glycosuria. All of the sulfapyridine was recovered in the urine within 24 to 48 hours, from 77 to 87 per cent appearing in the conjugated form.

Following the subcutaneous injection of sulfanilamide, the blood levels rose slowly to a maximum of between 8 to $10 \mathrm{mgm}$. per $100 \mathrm{ml}$. 6 hours after the injection was started. In Subject B (Table I and Figure 4) determinable amounts of free sulfanilamide were present 50 hours after commencement of injection; in a second subject only traces were present at this time. In both instances, however, levels between 2 and $3 \mathrm{mgm}$. of free, and 3 to $5 \mathrm{mgm}$. of total sulfanilamide per $100 \mathrm{ml}$. of blood were present 24 hours after injection. During the time when the blood levels were high, between 70 and 89 per cent of the drug was present in the free form.

All of the subcutaneously injected material was recovered from the urine in 96 hours; 38 per cent of this was present as the free and 62 per cent as the conjugated drug. The maximum excretion occurred during or shortly after a period of maximum diuresis. The essential difference between the urinary excretion of sulfapyridine after injection of the glucose compound and the excretion of sulfanilamide, when both were given subcutaneously, was the greater rapidity of the removal of glucose sulfapyridine from the blood.

\section{The effect of the oral administration of glucose sulfapyridine, sulfapyridine, and sulfanila- mide on the blood. levels and urinary excretion of sulfapyridine or sulfanilamide}

The blood levels after oral administration of glucose sulfapyridine in three subjects are shown in Figure 5, and the data for Subject B appear in Table I. The absorption from the gastro-intestinal tract was very slow. Appreciable concentrations did not appear in the blood until 24 hours after the beginning of ingestion. Unlike the findings after parenteral administration of the drug, there were large amounts of conjugated sulfapyridine present in the circulating blood. 


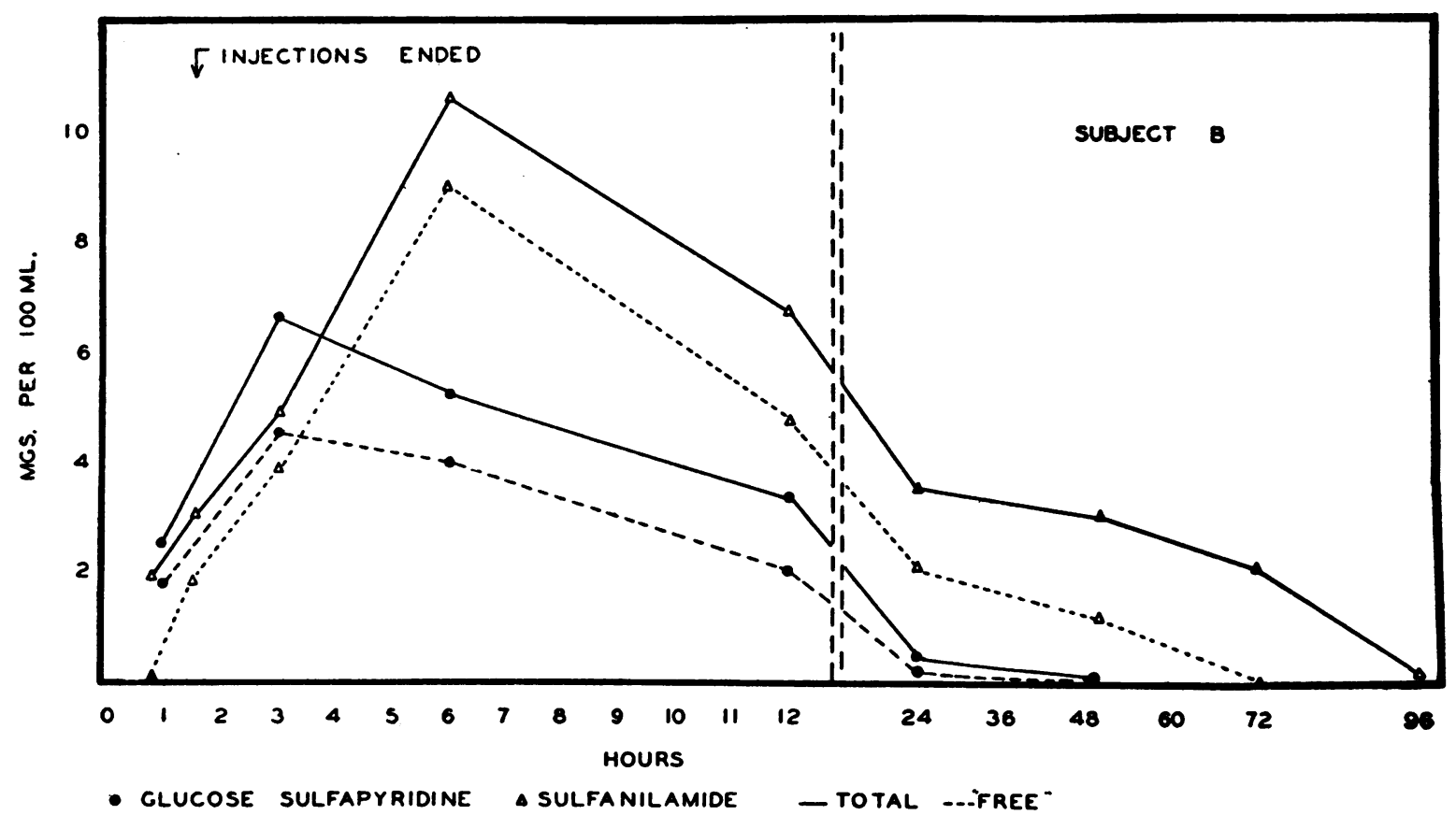

Fig. 4. Glucose Sulfapyridine and Sulfanilamide: Effect of Subcutangous Injection on the Blood Level

About 80 per cent of the drug administered was recovered from the urine in 72 hours. Approximately 25 per cent of this amount was in the free form. The maximum excretion of the drug occurred during the interval between 24 and 36 hours, which corresponded to maximum levels in the blood.
For purposes of further comparison, additional data on the effect of the administration of glucose sulfapyridine by the three different routes on the blood levels of sulfapyridine in Subject $A$ are shown in Figure 6. The data on the recovery of this drug from the urine of the same subject are shown in Figure 7.

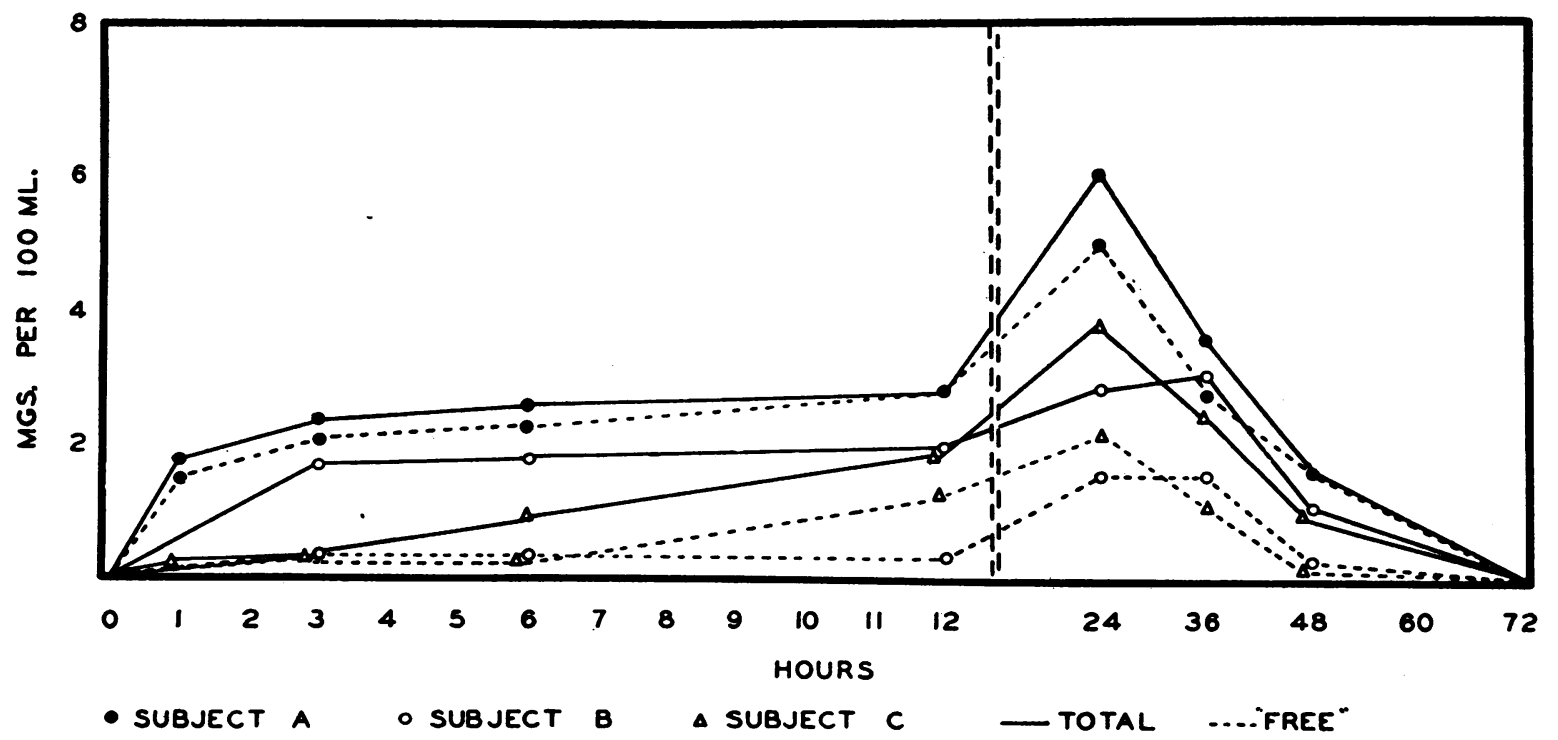

Fig. 5. Effect of Oral Administration of Glucose Sulfapyridine on the Blood Levet 


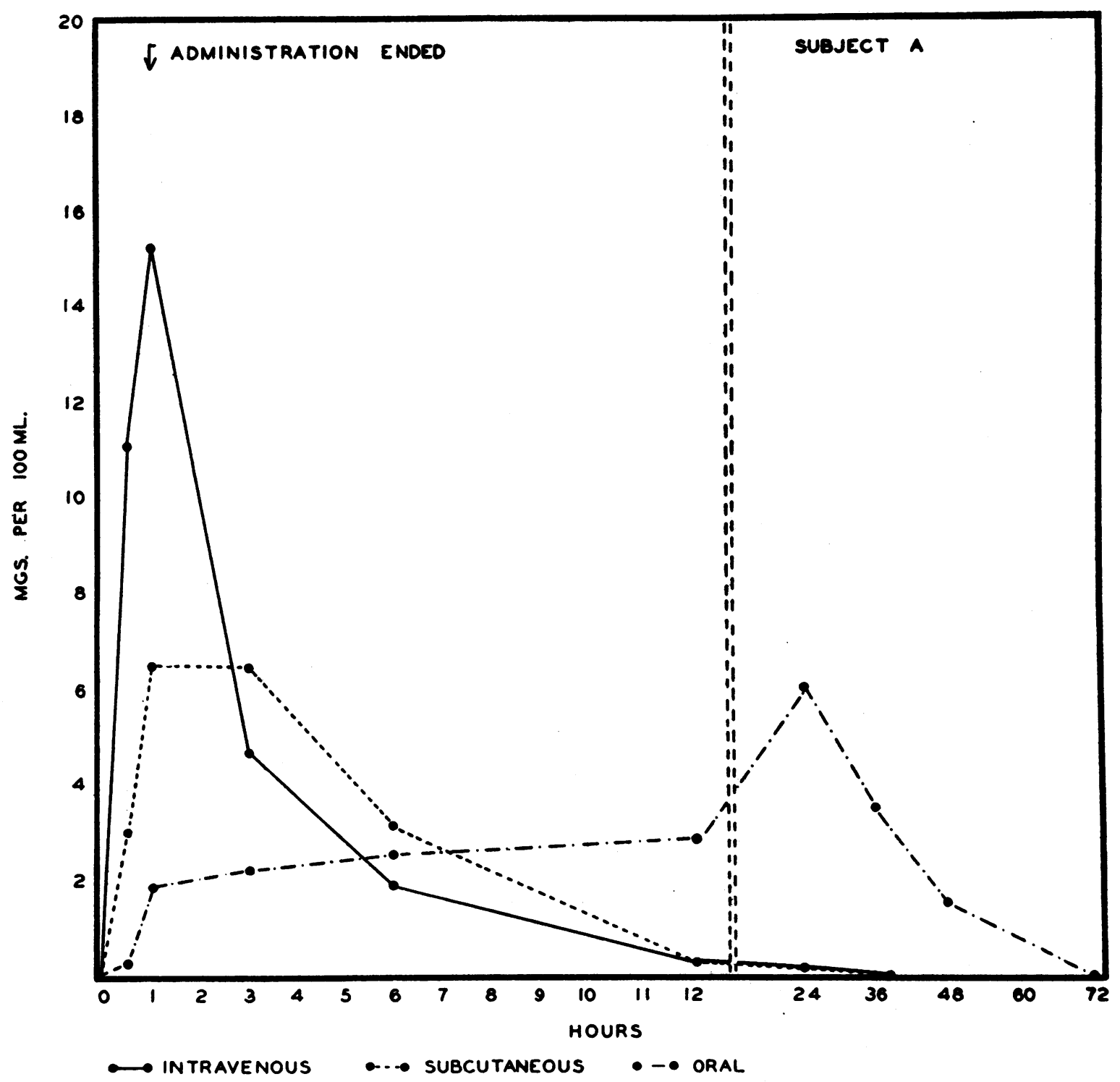

Fig. 6. Glucose Sulfapyridine: Effect of Route of Administration on Blood Level

When equivalent amounts of sulfapyridine or sulfanilamide were given orally, the rate of absorption from the gastro-intestinal tract was much faster than for the glucose compound. Values of 4 to $8 \mathrm{mgm}$. of free sulfapyridine or sulfanilamide per $100 \mathrm{ml}$. of blood were obtained 6 hours after the beginning of ingestion and determinable levels were present in the blood 24 hours later. A comparison of the effect of the administration of these two drugs with glucose sulfapyridine is shown in Figure 8 and in Table I. Similar results for the absorption and excretion of sulfapyridine and sul- fanilamide after oral ingestion have been reported by others $(5,7,8)$.

The distribution between red blood cells and plasma of certain derivatives of sulfanilamide in vitro

The fundamental differences in the behavior of glucose sulfapyridine and other sulfanilamide derivatives given intravenously and subcutaneously made appropriate a further consideration of the data in the light of blood clearance and distribution in the body. However, since the investi- 


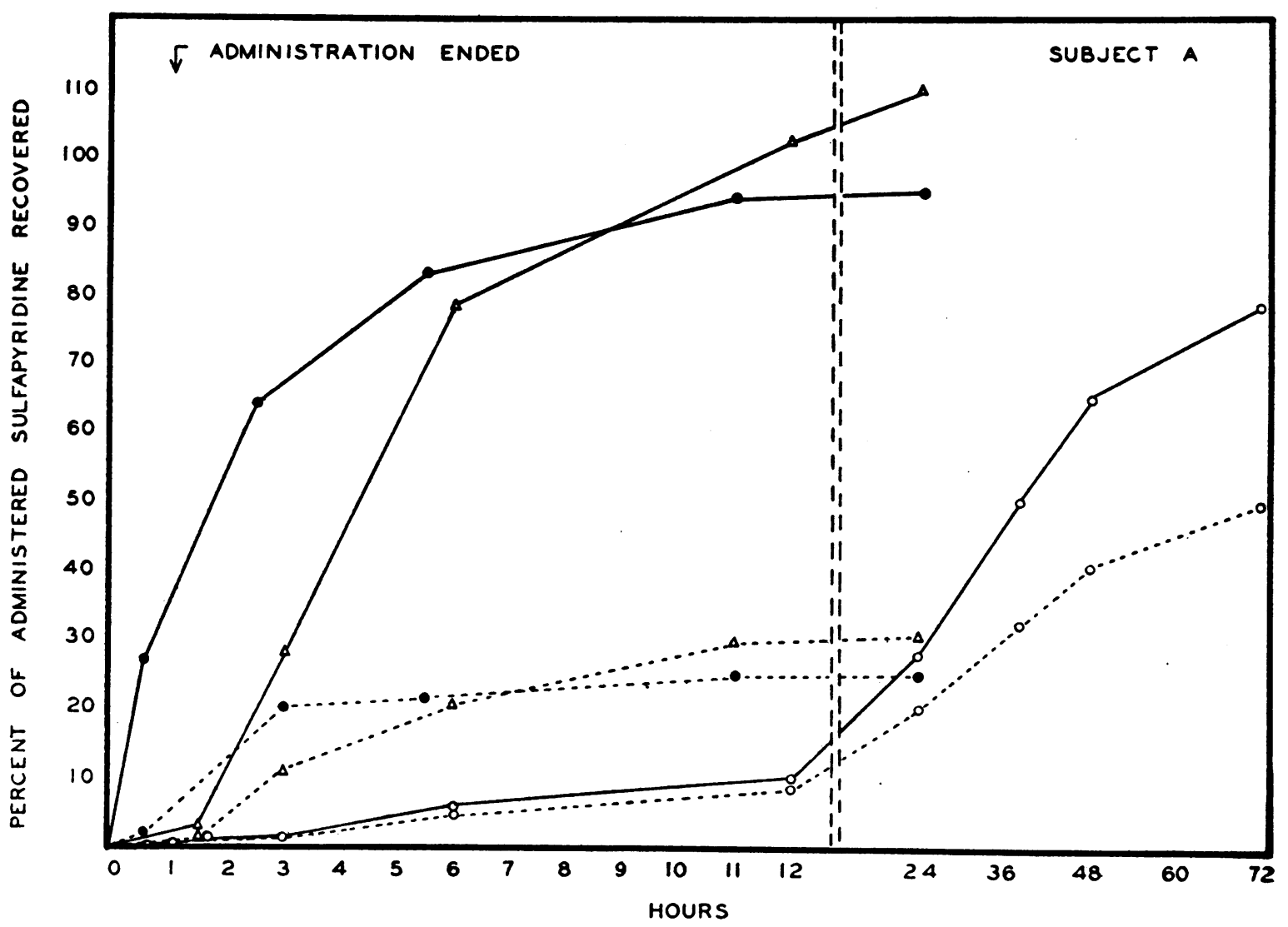

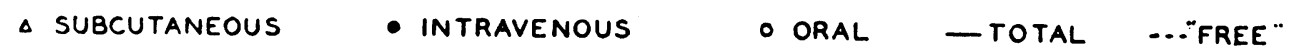

Fig. 7. Glucose Sulfapyridine: Effect of Route of Administration on Urinary Elimination

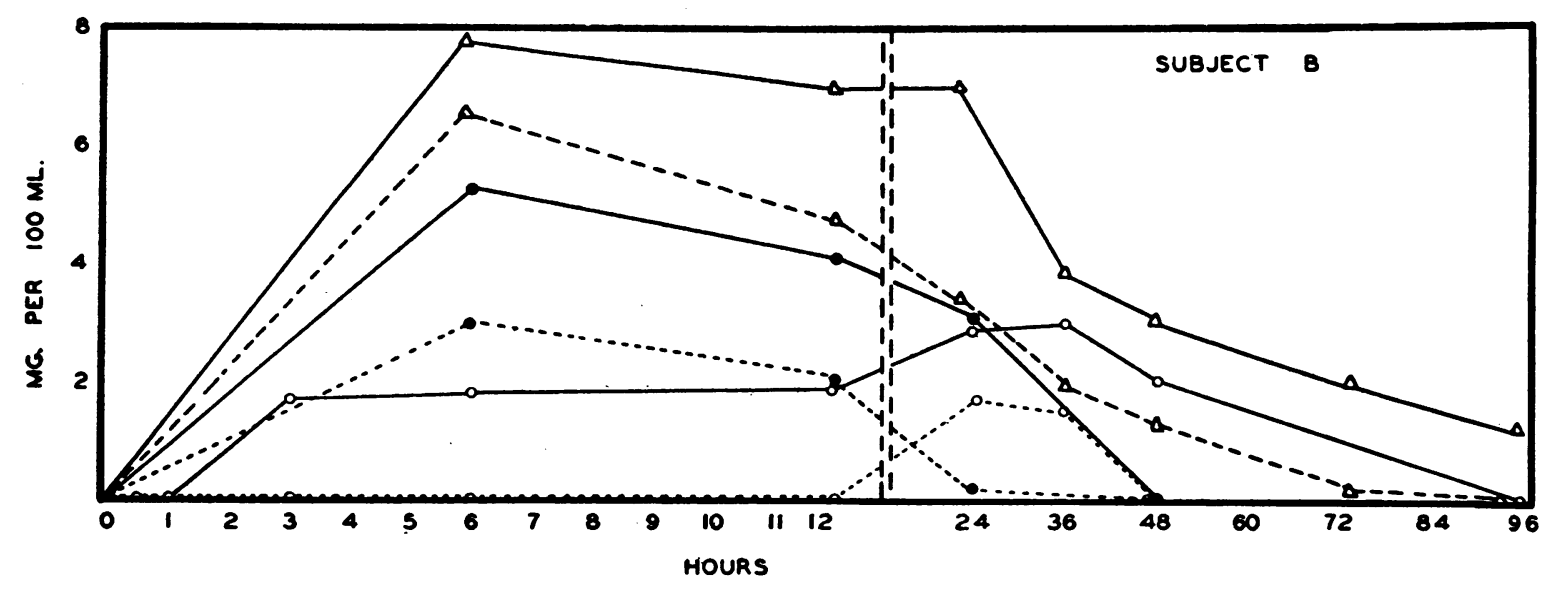

- glucose sulfapyridine - sulfapyridine a sulfanilamide - total ....free"

Fig. 8 Blood Levels after Oral Administration of Threg Sulfanilamide Derivatives 
TABLE III

Distribution between whole blood and plasma of glucose sulfapyridine, sodium sulfapyridine and sulfanilamide in vitro

\begin{tabular}{|c|c|c|c|c|c|c|c|}
\hline $\begin{array}{l}\text { Sub- } \\
\text { ject }\end{array}$ & $\begin{array}{c}\text { Compound } \\
\text { given }\end{array}$ & $\underset{\text { mixing }}{\text { Time from }}$ & $\begin{array}{l}\text { Whole } \\
\text { blood } \\
\text { val- } \\
\text { ues* }\end{array}$ & $\begin{array}{c}\text { Plas- } \\
\text { ma } \\
\text { val- } \\
\text { ues* }\end{array}$ & $\begin{array}{c}\text { Calcu- } \\
\text { lated val- } \\
\text { ues in } \\
\text { plasma for } \\
100 \mathrm{ml} \\
\text { blood }\end{array}$ & $\begin{array}{l}\text { Calcu- } \\
\text { lated val- } \\
\text { ues* in } \\
\text { cells for } \\
100 \mathrm{ml} \text {. } \\
\text { blood }\end{array}$ & $\begin{array}{l}\text { Hemar- } \\
\text { tocrit } \\
\text { (cor- } \\
\text { rected) }\end{array}$ \\
\hline $\mathbf{T}$ & $\begin{array}{l}\text { Glucose } \\
\text { Sulfapyridine }\end{array}$ & 10 minutes & $\begin{array}{c}\text { mom. } \\
\text { per } \\
100 \\
m l . \\
9.0\end{array}$ & $\begin{array}{c}\text { mom. } \\
\text { per } \\
100 \\
m l . \\
16.4\end{array}$ & 8.4 & 0.6 & 48.8 \\
\hline $\mathbf{T}$ & $\begin{array}{l}\text { Sodium } \\
\text { Sulfapyridine }\end{array}$ & 10 minutes & 8.7 & 8.6 & 4.9 & 3.8 & 48.8 \\
\hline Lo & $\begin{array}{l}\text { Glucose } \\
\text { Sulfapyridine }\end{array}$ & 10 minutes & 11.2 & 19.8 & 11.5 & 0 & 41.8 \\
\hline Lo & $\begin{array}{l}\text { Sodium } \\
\text { Sulfapyridine }\end{array}$ & 10 minutes & 7.7 & 8.2 & 4.8 & 2.9 & 41.8 \\
\hline F & $\begin{array}{l}\text { Glucose } \\
\text { Sulfapyridine }\end{array}$ & 10 minutes & 9.1 & 15.6 & 8.3 & 0.8 & 46.9 \\
\hline $\mathbf{F}$ & $\begin{array}{l}\text { Glucose } \\
\text { Sulfapyridine }\end{array}$ & 1 hour & 9.0 & 16.1 & 8.5 & 0.5 & 46.9 \\
\hline $\mathrm{F}$ & $\begin{array}{l}\text { Glucose } \\
\text { Sulfapyridine }\end{array}$ & 3 hours & 8.9 & 16.0 & 8.5 & 0 & 46.9 \\
\hline F & $\begin{array}{l}\text { Sodium } \\
\text { Sulfapyridine }\end{array}$ & 10 minutes & 8.3 & 8.7 & 4.6 & 3.7 & 46.9 \\
\hline F & $\begin{array}{l}\text { Sodium } \\
\text { Sulfapyridine }\end{array}$ & 1 hour & 8.2 & 8.6 & 4.6 & 3.6 & 46.9 \\
\hline F & $\begin{array}{l}\text { Sodium } \\
\text { Sulfapyridine }\end{array}$ & 3 hours & 8.2 & 8.6 & 4.6 & 3.6 & 46.9 \\
\hline F & Sulfanilamide & 10 minutes & 9.7 & 7.7 & 4.1 & 5.6 & 46.9 \\
\hline F & Sulfanilamide & 1 hour & 9.4 & 7.4 & 3.9 & 5.5 & 46.9 \\
\hline$F$ & Sulfanilamide & 3 hours & 9.3 & 7.5 & 4.0 & 5.3 & 46.9 \\
\hline Low & $\begin{array}{l}\text { Glucose } \\
\text { Sulf apyridine }\end{array}$ & 10 minutes & 9.9 & 18.9 & 9.5 & 0 & 50.2 \\
\hline Low & $\begin{array}{l}\text { Glucose } \\
\text { Sulfapyridine }\end{array}$ & 1 hour & 9.7 & 17.6 & 8.8 & 0.9 & 50.2 \\
\hline Low & $\begin{array}{l}\text { Glucose } \\
\text { Sulfapyridine }\end{array}$ & 3 hours & 9.9 & 18.5 & 9.3 & 0.6 & 50.2 \\
\hline Low & $\begin{array}{l}\text { Sodium } \\
\text { Sulfapyridine }\end{array}$ & 10 minutes & 8.1 & 8.7 & 4.4 & 3.7 & 50.2 \\
\hline Low & $\begin{array}{l}\text { Sodium } \\
\text { Sulfapyridine }\end{array}$ & 1 hour & 8.1 & 8.8 & 4.4 & 3.7 & 50.2 \\
\hline Low & $\begin{array}{l}\text { Sodium } \\
\text { Sulfapyridine }\end{array}$ & 3 hours & 8.1 & 8.2 & 4.1 & 4.0 & 50.2 \\
\hline Low & Sulfanilamide & 10 minutes & 8.5 & 7.6 & 3.8 & 4.7 & 50.2 \\
\hline Low & Sulfanilamide & 1 hour & 9.3 & 7.5 & 3.8 & 5.5 & 50.2 \\
\hline Low & Sulfanilamide & 3 hours & 9.7 & 7.4 & 3.7 & 6.0 & 50.2 \\
\hline
\end{tabular}

* Sulfapyridine or sulfanilamide.

gation had been made on whole blood, the distribution of these compounds between red blood cells and plasma was studied.

The distribution of glucose sulfapyridine, sodium sulfapyridine and sulfanilamide between red blood cells and plasma was determined in vitro at various times up to 3 hours after their addition to oxalated blood. The results are given in Table
III. Glucose sulfapyridine was present only in the plasma, sodium sulfapyridine was equally distributed between the red blood cells and the plasma, and sulfanilamide showed a slightly greater concentration in the red cells than in the plasma. This increased concentration in the red cells of sulfanilamide was pointed out previously by Sise (6). This slight increase in concentration in the red blood cells was disregarded in subsequent calculations.

\section{The distribution of glucose sulfapyridine between red cells and plasma in vivo}

Two subjects were given 4.75 grams of glucose sulfapyridine intravenously, two others received the same amount subcutaneously and three were given 12.5 grams of the drug orally. Hematocrits were determined and estimations of sulfapyridine were made on the whole blood and plasma at appropriate intervals. The data are shown in Table IV. Like the in vitro results, glucose sulfapyridine showed little penetration into the red blood cells when given intravenously or subcutaneously, while following oral administration approximately one-third of the sulfapyridine found in the whole blood was present in the red cells.

TABLE IV

Distribution of sulfapyridine between red blood cells and plasma when glucose sulfapyridine was administered by various routes

\begin{tabular}{|c|c|c|c|c|c|c|c|}
\hline $\begin{array}{l}\text { Sub-- } \\
\text { jeet }\end{array}$ & Route & $\begin{array}{c}\text { Time after } \\
\text { adminis- } \\
\text { tration }\end{array}$ & $\begin{array}{l}\text { Whole } \\
\text { blood } \\
\text { sulfa- } \\
\text { pyri- } \\
\text { dine }\end{array}$ & $\begin{array}{l}\text { Plas- } \\
\text { ma } \\
\text { sulfa- } \\
\text { pyri- } \\
\text { dine }\end{array}$ & $\begin{array}{c}\text { Calcu- } \\
\text { lated } \\
\text { sulfapyri- } \\
\text { dine in } \\
\text { plasma for } \\
100 \mathrm{ml} \text {. } \\
\text { blood }\end{array}$ & $\begin{array}{l}\text { Calcu- } \\
\text { lated } \\
\text { sulfapyri- } \\
\text { dine in } \\
\text { cells for } \\
100 \mathrm{ml} \text {. } \\
\text { blood }\end{array}$ & $\begin{array}{l}\text { Hema- } \\
\text { tocrit } \\
\text { (cor- } \\
\text { rected) }\end{array}$ \\
\hline & & & $\begin{array}{l}\text { mom. } \\
\text { in } 100 \\
\mathrm{ml} .\end{array}$ & $\begin{array}{c}\text { mom. } \\
\text { in } 100 \\
\mathrm{ml} .\end{array}$ & & & \\
\hline I & Intravenous & 1 hour & 10.8 & 17.2 & 10.5 & 0 & 38.9 \\
\hline I & Intravenous & 3 hours & 7.4 & 10.8 & 6.6 & 0.8 & 38.9 \\
\hline II & Intravenous & 1 hour & 9.1 & 16.3 & 9.3 & 0 & 43.3 \\
\hline II & Intravenous & 3 hours & 4.1 & 7.1 & 4.0 & 0 & 43.3 \\
\hline III & Subcutaneous & 3 hours & 3.9 & 5.5 & 3.4 & 0.5 & 38.6 \\
\hline III & Subcutaneous & 4 hours & 3.3 & 4.6 & 2.8 & 0.5 & 38.6 \\
\hline IV & Subcutaneous & 3 hours & 4.3 & 7.8 & 4.4 & 0 & 42.8 \\
\hline IV & Subcutaneous & 4 hours & 3.9 & 5.6 & 3.2 & 0.7 & 42.8 \\
\hline $\mathbf{v}$ & Oral & 17 hours & 10.5 & 12.5 & 6.8 & 3.7 & 46.4 \\
\hline VI & Oral & 11 hours & 10.6 & 11.0 & 6.1 & 4.5 & 45.1 \\
\hline VII & Oral & $11 !$ hours & 12.0 & 14.6 & 8.3 & 3.7 & 43.2 \\
\hline
\end{tabular}


The distribution of glucose sulfapyridine in the body water after both intravenous and subcutaneous injection shows that the drug is confined essentially to the extra-cellular water (Table V).

TABLE V

Distribution of glucose sulfapyridine

\begin{tabular}{c|c|c|c|c|c|c}
\hline \hline Patient & Route & $\begin{array}{c}\text { Time after } \\
\text { ofeginning } \\
\text { of injection } \\
\text { in hours }\end{array}$ & $\begin{array}{c}\text { Total sulfa- } \\
\text { pyridine in } \\
\text { serum water } \\
\text { at end of } \\
\text { period }\end{array}$ & $\begin{array}{c}\text { Total sulfa- } \\
\text { pyridine } \\
\text { excreted in } \\
\text { urine through } \\
\text { end of period }\end{array}$ & $\begin{array}{c}\text { Liters } \\
\text { of } \\
\text { body } \\
\text { water }\end{array}$ & $\begin{array}{c}\text { Per } \\
\text { cent of } \\
\text { body } \\
\text { weight }\end{array}$ \\
\hline B & Intravenous & $\begin{array}{c}\text { hours } \\
3\end{array}$ & $\begin{array}{c}\text { mgm. } \\
8.4\end{array}$ & $\begin{array}{c}\text { mom. } \\
2887\end{array}$ & $\begin{array}{c}\text { liters } \\
25\end{array}$ & $\begin{array}{c}\text { per cent } \\
36\end{array}$ \\
\hline A & Intravenous & 3 & 6.4 & 3024 & 31 & 53 \\
\hline C & Intravenous & 3 & 7.4 & 2558 & 33 & 49 \\
\hline B & Subcutaneous & 12 & 4.8 & 3518 & 23 & 33 \\
\hline A & Subcutaneous & 6 & 4.6 & 3734 & 28 & 48 \\
\hline
\end{tabular}

Sodium sulfapyridine, sulfapyridine and sulfanilamide, when given by each of the three routes, were distributed over the total body water. Unfortunately, variations in the amounts of free and conjugated sulfapyridine or sulfanilamide, and secretion of these compounds into the gastrointestinal tract prohibit determination of the distribution. In all instances, however, the apparent distribution of sulfanilamide and sulfapyridine or its sodium salt was in a volume of water in excess of 70 per cent of the body weight, and this was also true following the oral administration of glucose sulfapyridine.

\section{The renal clearance of sulfanilamide and certain of its derivatives when administered by different routes}

The clearance values given in Table VI were obtained by recalculation of the whole blood data on three subjects, making use of the distributions between red cells and plasma to obtain serum levels. When given by the intravenous route, glucose sulfapyridine differed sharply from either sodium sulfapyridine or sulfanilamide. The latter two substances were cleared at rates indicating a considerable degree of tubular reabsorption while the glucose compound was cleared at a rate usually associated with simple glomerular filtration.

When glucose sulfapyridine and sulfanilamide were given subcutaneously, the clearances for the
TABLE VI

Blood clearances of glucose sulfapyridine, sodium sulfapyridine and sulfanilamide when administered by different routes

\begin{tabular}{|c|c|c|c|c|c|c|c|c|c|c|}
\hline \multirow{2}{*}{$\begin{array}{l}P_{\text {a- }} \\
\text { tient }\end{array}$} & \multirow{2}{*}{ Compound } & \multirow{2}{*}{ Route } & \multirow{2}{*}{$\begin{array}{l}\text { Time } \\
\text { of pe- } \\
\text { riod }\end{array}$} & \multicolumn{2}{|c|}{$\begin{array}{c}\text { Average } \\
\text { serum* con- } \\
\text { centration } \\
\text { (calculated) }\end{array}$} & \multicolumn{2}{|c|}{$\begin{array}{c}\text { Total drug* } \\
\text { excereted in } \\
\text { urine for } \\
\text { period }\end{array}$} & \multicolumn{3}{|c|}{$\begin{array}{l}\text { Blood cleared } \\
\text { per minute }\end{array}$} \\
\hline & & & & Free & Total & Free & Total & Free & $\left|\begin{array}{c}\text { Con- } \\
\text { ju- } \\
\text { gated }\end{array}\right|$ & Tota \\
\hline B & $\begin{array}{l}\text { Glucose } \\
\text { Sulfapyridine }\end{array}$ & $\begin{array}{l}\text { Intra- } \\
\text { venous }\end{array}$ & $\begin{array}{c}\min \\
\text { utes } \\
120\end{array}$ & mom. & & mom. & $\begin{array}{l}\text { mom. } \\
2325\end{array}$ & $\mathrm{ml}$. & $m l$. & $\begin{array}{l}m l . \\
125\end{array}$ \\
\hline A & $\begin{array}{l}\text { Glucose } \\
\text { Sulfapyridine }\end{array}$ & $\begin{array}{l}\text { Intrar } \\
\text { venous }\end{array}$ & 120 & & 12.7 & & 1737 & & & 114 \\
\hline C & $\begin{array}{l}\text { Glucose } \\
\text { Sulfapyridine }\end{array}$ & $\begin{array}{l}\text { Intra- } \\
\text { venous }\end{array}$ & 120 & & 12.0 & & 1718 & & & 90 \\
\hline B & \begin{tabular}{|l|} 
Sodium \\
Sulfapyridine
\end{tabular} & $\begin{array}{l}\text { Intra- } \\
\text { venous }\end{array}$ & 120 & 7.3 & 8.5 & 122 & 192 & 14 & 48 & 19 \\
\hline A & $\begin{array}{l}\text { Sodium } \\
\text { Sulfapyridine }\end{array}$ & $\begin{array}{l}\text { Intra- } \\
\text { venous }\end{array}$ & 180 & 7.5 & 7.7 & 429 & 508 & 32 & & 37 \\
\hline C & $\begin{array}{l}\text { Sodium } \\
\text { Sulfapyridine }\end{array}$ & $\begin{array}{l}\text { Intrar } \\
\text { venous }\end{array}$ & 120 & 7.8 & 10.0 & 181 & 256 & 20 & 28 & 21 \\
\hline B & Sulfanilamide & $\begin{array}{l}\text { Intra- } \\
\text { venous }\end{array}$ & 120 & 10.0 & 11.5 & 240 & 301 & 20 & 34 & 23 \\
\hline D & Sulfanilamide & $\begin{array}{l}\text { Intra- } \\
\text { venous }\end{array}$ & 195 & 5.7 & 7.1 & 475 & 728 & 41 & 92 & 52 \\
\hline B & $\begin{array}{l}\text { Glucose } \\
\text { Sulfapyridine }\end{array}$ & $\begin{array}{l}\text { Subcu- } \\
\text { taneous }\end{array}$ & 360 & & 6.2 & & 1102 & & & 49 \\
\hline A & \begin{tabular}{|} 
Glucose \\
Sulfapyridine
\end{tabular} & $\begin{array}{l}\text { Subcu- } \\
\text { taneous }\end{array}$ & 120 & & 9.0 & & 1267 & & & 117 \\
\hline C & $\begin{array}{l}\text { Glucose } \\
\text { Sulfapyridine }\end{array}$ & $\begin{array}{l}\text { Subcu- } \\
\text { taneous }\end{array}$ & 180 & & 7.9 & & 1714 & & & 120 \\
\hline B & Sulfanilamide & $\mid \begin{array}{l}\text { Subcu- } \\
\text { taneous }\end{array}$ & 180 & 5.8 & 7.0 & 240 & 346 & 23 & 49 & 27 \\
\hline D & Sulfanilamide & \begin{tabular}{|l|} 
Subcu- \\
taneous
\end{tabular} & 360 & 5.1 & 6.8 & 645 & 1057 & 36 & 68 & 43 \\
\hline B & $\begin{array}{l}\text { Glucose } \\
\text { Sulfapyridine }\end{array}$ & Oral & 720 & 1.4 & 2.7 & 236 & 1069 & 23 & 89 & 55 \\
\hline A & $\begin{array}{l}\text { Glucose } \\
\text { Sulfapyridine }\end{array}$ & Oral & 720 & 3.6 & 4.3 & 592 & 954 & 23 & 72 & 32 \\
\hline C & $\begin{array}{l}\text { Glucose } \\
\text { Sulfapyridine }\end{array}$ & Oral & 720 & 1.7 & 2.9 & 299 & 986 & 24 & 80 & 47 \\
\hline B & Sulfapyridine & Oral & 720 & 2.1 & 5.0 & 166 & 1182 & 11 & 49 & 33 \\
\hline $\mathbf{A}$ & Sulfapyridine & Oral & 720 & 3.6 & 4.0 & 606 & 804 & 23 & & 28 \\
\hline C & Sulfapyridine & Oral & 360 & 3.7 & 5.6 & 506 & 1183 & 38 & 99 & 59 \\
\hline B & Sulfanilamide & Oral & 720 & 1.4 & 3,2 & 118 & 437 & 12 & 25 & 19 \\
\hline $\mathbf{A}$ & Sulfanilamide & Oral & 360 & $3.5 t$ & $4.5 t$ & 596 & 895 & 47 & 111 & 61 \\
\hline C & Sulfapyridine & Oral & 360 & 4.0 & 5.7 & 530 & 1400 & 37 & 142 & 69 \\
\hline
\end{tabular}

* = Sulfapyridine or sulfanilamide.

$\dagger=$ Determinations were done on serum instead of whole blood.

glucose compound were elevated above that for sulfanilamide. With one exception (Subject B) the values for the clearances were similar to those found after intravenous administration.

When given by the oral route glucose sulfapyridine, sulfapyridine and sulfanilamide all gave 
similar values. For all the compounds given orally the clearance values indicated marked tubular reabsorption. The clearance of the conjugated form of sulfanilamide or sulfapyridine was always higher than the free form. The tubules apparently selectively reabsorb the free form of sulfapyridine and sulfanilamide.

\section{DISCUSSION}

The data presented show that, when glucose sulfapyridine is given intravenously or subcutaneously, its behavior is quite different from that of the other derivatives of sulfanilamide used in this study when they are given by the same route. The levels of total sulfapyridine in the blood are comparatively higher but these high levels are not maintained. After a brief interval no circulating sulfapyridine is demonstrable.

From the clearance data it is possible to say that intravenous glucose sulfapyridine is eliminated with very little reabsorption while sulfapyridine and its sodium salt, given by parenteral or oral routes, and glucose sulfapyridine, given by mouth, undergo considerable tubular reabsorption. This would indicate that glucose sulfapyridine given intravenously or subcutaneously is not converted to sulfapyridine or sodium sulfapyridine but retains its identity in the blood and is excreted at a different rate. The low clearance values following the oral administration are of the same order of magnitude as those obtaining for sulfapyridine. There is a corresponding increase in the concentration of sulfapyridine in the red blood cells. It would appear, therefore, that orally administered glucose sulfapyridine is largely converted to sulfapyridine or its sodium salt before absorption.

Calculations of the distribution of glucose sulfapyridine given by parenteral route show that the drug is distributed over the extracellular fluid. In this regard it behaves in sharp contrast to sulfapyridine and sodium sulfapyridine which, by approximate calculation, appear to be distributed over the total body water. The distribution of the various compounds between red blood cells and plasma offers still further confirmation of these observations. The oral administration of glucose sulfapyridine differs from that of sulfapyridine and sulfanilamide. The absorption is slower, maximum concentrations are lower and are found 24 hours or longer after the ingestion of the drug.

These observations are interpreted as meaning that, following intravenous or subcutaneous administration, glucose sulfapyridine circulates in the blood unchanged. However, it would appear that the material present in the urine was not glucose sulfapyridine. This is suggested by the failure to show any glycosuria comparable to the amount of sulfapyridine present in the urine, and also by the presence of a conjugated compound determinable as such by the Marshall and Litchfield method (3).

The results of studies on the pneumococcidal activity of glucose sulfapyridine in human blood were in accord with these findings (2). The addition of glucose sulfapyridine to blood in high concentration in vitro produced no pneumococcidal activity. On prolonged standing at $37^{\circ} \mathrm{C}$. only slight bacteriostasis became evident. When blood was withdrawn from patients to whom glucose sulfapyridine was given intravenously or subcutaneously, no pneumococcidal power was evident. Even should some activity occur in the blood after prolonged standing, the present data show that the drug is removed too quickly from the circulating blood for such a possibility to arise in vivo after parenteral administration. Following the oral administration of glucose sulfapyridine the pneumococcidal power of the circulating blood was practically the same as that demonstrable with blood having similar concentrations of drug after sulfapyridine itself had been given. These studies offer further evidence that the substance present in the blood after intravenous or subcutaneous administration of glucose sulfapyridine is not free sulfapyridine. They also suggest that the oral administration of glucose sulfapyridine results in its decomposition with the formation of active sulfapyridine.

It is of interest that such a slight procedure as boiling a drug in glucose solution should so change its biochemical and physiological activity. It is suggested that such studies as the ones presented, when applied to new therapeutic substances of this type, may be helpful in determining the potentialities of a drug. Glucose sulfapyridine by these criteria, when given by the 
parenteral route, has characteristics which indicate that it is probably not useful therapeutically. The rapidity with which it leaves the blood stream, its poor distribution and its apparent failure to hydrolize into an active substance all militate against its usefulness.

\section{CONCLUSIONS}

1. Glucose sulfapyridine administered intravenously or subcutaneously gives high levels of the drug in the blood but is rapidly excreted and appears to circulate in a form which does not behave like sulfapyridine.

2. The data for the clearances of glucose sulfapyridine after its intravenous or subcutaneous administration indicate that little or no reabsorption of glucose sulfapyridine takes place.

3. Glucose sulfapyridine administered orally is absorbed slowly. In other respects, however, the drug present in the blood after its absorption from the gastro-intestinal tract behaves in the same manner as when sulfapyridine itself is given.

4. Glucose sulfapyridine given intravenously or subcutaneously does not enter the red blood cells, and is apparently distributed only in the extracellular fluids.

The authors gratefully acknowledge the suggestions and assistance of Dr. A. W. Winkler of the Department of Internal Medicine, Yale University Medical School, in the interpretation of the clearance and distribution data.

\section{BIBLIOGRAPHY}

1. Finland, M., Lowell, F. C., Spring, W. C., Jr., and Taylor, F. H. L., Parenteral sulfapyridine. The intravenous use of sodium sulfapyridine and a report of clinical and laboratory observations on the use of a glucose-sulfapyridine solution. Ann. Int. Med. (In press).

2. Lowell, F. C., Spring, W. C., Jr., and Finland, M., Bactericidal action of sodium sulfapyridine and of a glucose-sulfapyridine solution in human blood. J. Clin. Invest., 1940, 19, 215.

3. Marshall, E. K., Jr., and Litchfield, J. T., Jr., Determination of sulfanilamide. Science, 1938, 88, 85.

4. Folin, O., A Laboratory Manual of Biological Chemistry. D. Appleton-Century Co., New York, 1934, 5th Edition, pp. 301-307.

5. Stewart, J. D., Rourke, G. M., and Allen, J. G., Excretion of sulfanilamide. J. A. M. A., 1938, 110, 1885.

6. Sise, H. S., The distribution of sulfanilamide and acetylsulfanilamide between cells and extracellular fluid. Proc. Soc. Exp. Biol. and Med., 1939, 40, 451.

7. Baines, E. J., and Wien, R., The absorption and excretion of 2-sulphanilyl-aminopyridine. Quart. J. Pharm. and Pharmacol., 1939, 12, 4.

8. Marshall, E. K., Jr., and Long, P. H., The intravenous use of sodium sulfapyridine. J. A. M. A., 1939, $112,1671$. 